\title{
ALEKSANDRA TŁUŚCIAK-DELIOWSKA
}

Akademia Pedagogiki Specjalnej im. Marii Grzegorzewskiej

$w$ Warszawie

\section{INTERWENCJA RÓWIEŚNIKÓW W SYTUACJI DRECCZENIA SZKOLNEGO. ROLA CZYNNIKÓW KONTEKSTOWYCH. IMPLIKACJE PRAKTYCZNE}

\begin{abstract}
Tłuściak-Deliowska Aleksandra, Interwencja rówieśników w sytuacji dręczenia szkolnego. Rola czynników kontekstowych. Implikacje praktyczne [Peer Intervention in Bullying Situations. The Role of Contextual Factors. Practical Implications]. Studia Edukacyjne nr 32, 2014, Poznań 2014, pp. 303-320. Adam Mickiewicz University Press. ISBN 978-83-232-2837-0. ISSN 1233-6688

Bullying is a group process, a social phenomenon and each group member could take on a different role. Many studies have shown that peers are present in most cases of school bullying, but behave rather in a way that perpetuates or even enhances peer violence. Prevention and intervention programs aimed at reducing school violence should take into account the role of bystanders. The point is to influence students, especially witnesses of school violence, who do nothing to stop it.

The aim of this article is to: (1) indicate the main mechanisms explaining the behavior of students who witness school bullying, (2) determine, on the basis of empirical studies, the factors that may increase the likelihood of positive interventions of bullying bystanders, and (3) formulate practical implications.
\end{abstract}

Key words: bullying, bystanders, school climate, peer interventions, contextual factors

\section{Wprowadzenie}

Dopiero od niedawna w pracach empirycznych zaczęto coraz bardziej eksplorować rolę grupy rówieśniczej w dręczeniu szkolnym (ang. bullying)1.

1 Por. D.J. Pepler, W.M. Craig, A peek behind the fence: naturalistic observations of aggressive children with remote audiovisual recording, Developmental Psychology, 1995, 31, s. 548-553; C. Salmivalli i in., Bullying and the Peer Group: A Review, Aggression and Violent Behavior, 
Uczniowie będący świadkami dręczenia szkolnego, mający świadomość istnienia tego zjawiska w swoim środowisku, mogą mieć niezwykle istotny wpływ na nie, zarówno pozytywny, jak i negatywny ${ }^{2}$. Z wielu badań ${ }^{3}$ wynika jednak, że pomimo tego, iż większość uczniów wyraża dezaprobatę wobec przemocy rówieśniczej, tylko niewielki ich odsetek przejawia swoją postawę w działaniu i próbuje interweniować w sytuacji dręczenia szkolnego rówieśników. Wręcz przeciwnie, większość uczniów zachowuje się w sposób, który raczej podtrzymuje, czy wręcz wzmacnia „bullying”. Stwierdzono także, że "bullying" występuje częściej w szkołach, w których zachowania uczniów-świadków wzmacniają zachowania agresywne, niż w tych, w których uczniowie podejmują zachowania mające na celu pomoc ofierze przemocy ${ }^{4}$. W związku $\mathrm{z}$ tym większą uwagę $\mathrm{w}$ programach profilaktycznych, mających na celu zapobieganie i ograniczanie przemocy szkolnej, należałoby skupić nie tylko na ofiarach przemocy, czy jej sprawcach, jak miało to miejsce dotychczas, ale na całej grupie rówieśniczej i do grupy jako całości kierować owe programy. Programy profilaktyczne i interwencyjne powinny uwzględniać rolę uczniów-świadków. Chodzi bowiem o to, aby wpłynąć na uczniów-świadków dręczenia szkolnego, szczególnie na tych, którzy widzą przemoc, ale nie robią nic w kierunku jej powstrzymania.

Intencją moją w niniejszym artykule jest po pierwsze, wskazanie głównych mechanizmów wyjaśniających zachowanie uczniów będących świadkami dręczenia szkolnego. Po drugie, ustalenie na podstawie studiów empirycznych czynników, które mogą zwiększać prawdopodobieństwo pozytywnych reakcji uczniów-świadków. Wreszcie, sformułowanie wniosków praktycznych.

\section{Społeczny kontekst dręczenia szkolnego - dlaczego obserwujący rówieśnicy nie reagują?}

„Bullying” (dręczenie, znęcanie, prześladowanie) jest specyficznym rodzajem przemocy rówieśniczej, który polega na podejmowaniu krzywdzą-

2010, 15, s. 1-15 i 112-120; A. Tłuściak-Deliowska, Deklaracje postaw wobec przemocy rówieśniczej wśród gimnazjalistów, Psychologia Rozwojowa, 2013, 3.

2 S.M. Swearer i in., What Can Be Done About School Bullying? Linking Research to Educational Practice, Educational Researcher, 2010, 39(1), s. 39.

3 Por. D.J., Pepler, W.M. Craig, A peek behind the fence, s. 548-553; C. Salmivalli i in., Bullying and the Peer Group, s. 1-15; C. Salmivalli, M. Voeten, Connections between attitudes, group norms, and behavior in bullying situations, International Journal of Behavior Development, 2004, 28(3), s. 246-258.

${ }^{4}$ A. Kärnä i in., Vulnerable children in varying classroom contexts: bystanders' behaviors moderate the effects of risk factors on victimization, Merrill-Palmer Quarterly, 2010, 56(3), s. 261-282. 
cego zachowania ukierunkowanego na innego ucznia lub grupę uczniów. To zachowanie agresywne powtarza się zazwyczaj w czasie i uwzględnia prawdziwą lub pozorną nierównowagę siły, kiedy ofiara nie może (lub nie chce) obronić się przed napastnikiem ${ }^{5}$. Jak dowodzą badania kanadyjskie ${ }^{6}$, fińskie i norweskie ${ }^{7}$, australijskie ${ }^{8}$, a także polskie ${ }^{9}$, do szykanowania w szkole dochodzi na ogół w obecności świadków. Właśnie oni stanowią najliczniejszą grupę w klasie ${ }^{10}$. Ten typ przemocy stanowi demonstrację „siły grupy rówieśniczej", w którym każda osoba z grupy uczestniczy i odgrywa różne role moderujące zachowania agresywne11. Uczniowie będący świadkami mogą aktywnie zainterweniować i powstrzymać agresora, mogą także wspierać i zachęcać agresywnego rówieśnika do podtrzymania działania lub mogą bezczynnie przyglądać się zaistniałej sytuacji. Jak dowodzą badania12, większość uczniów przyjmuje raczej bierną rolę obserwatorów. A takie zachowanie może zostać przez sprawcę zinterpretowane jako aprobata dla jego agresywnych działań13, co je dodatkowo wzmacnia. Rigby uważa, że im więcej świadków, tym dłużej trwa znęcanie się ${ }^{14}$.

Pojawia się zatem pytanie: dlaczego tak niewielu uczniów reaguje w sytuacji bycia świadkiem dręczenia szkolnego? Dlaczego uczniowie raczej wspierają (choć czasami nieświadomie) agresora, niż pomagają ofierze?

${ }^{5}$ D. Olweus, Przemoc w szkołach. Prezentacja na Europejskim Kongresie Przeciwdziałania Przemocy Szkolnej, Warszawa, 15.09.2010; tegoż, Mobbing. Fala przemocy w szkole. Jak ja powstrzymać? przekł. D. Jastrun, Warszawa 2007.

6 Por. D.J., Pepler, W.M. Craig, A peek behind the fence, s. 548-553.

7 Zob. C. Salmivalli i in., Bullying and the Peer Group, s. 1-15 i 112-120; C. Salmivalli, M. Voeten, E. Poskiparta, Bystanders Matter: Association Beetween Reinforcing, Defending and the Frequency of Bullying Behavior in Classrooms, Journal of Clinical Child \& Adolescence Psychology, 2011, 40(5), s. 668-676.

8 K. Rigby, Przemoc w szkole. Jak ją ograniczać. Poradnik dla rodziców i pedagogów, przekł. R. Mitoraj, Kraków 2010.

${ }^{9}$ Zob. A. Giza-Poleszczuk, A. Komendant-Brodowska, A. Baczko-Dombi, Przemoc w szkole. Raport z badań. Maj 2011; A. Tłuściak-Deliowska, Deklaracje postaw wobec przemocy rówieśniczej.

${ }^{10} \mathrm{~K}$. Fenik, Psychologiczne aspekty bullyingu: perspektywa sprawcy, ofiary i świadka. Materiał z konferencji „Szkoła wolna od przemocy. Jak sobie radzić z bullyingiem?”, 11.04.2013, Warszawa; dokument pobrany z: http://www.ore.edu.pl/strona-ore/index.php?option=com phocadownload\&view=category\&id=55:profilaktyka-agresji-i-przemocy\&Itemid=1148 [dostęp: 07.10.2013].

${ }^{11}$ C. Salmivalli, Participant role approach to school bullying: implications for intervention, Journal of Adolescence", 1999, 22, s. 453-459.

12 Por. D.J., Pepler, W.M. Craig, A peek behind the fence, s. 548-553; C. Salmivalli i in., Bullying and the Peer Group, s. 1-15.

13 Por. C. Salmivalli i in., Bullying and the Peer Group, s. 1-15; I. Whitney, P.K. Smith, A survey of the nature and extent of bullying in junior/Middle and secondary schools, Educational Research, 1993, 35, s. 3-25; A. Tłuściak-Deliowska, Deklaracje postaw wobec przemocy rówieśniczej.

${ }^{14}$ K. Rigby, Przemoc $w$ szkole, s. 54. 


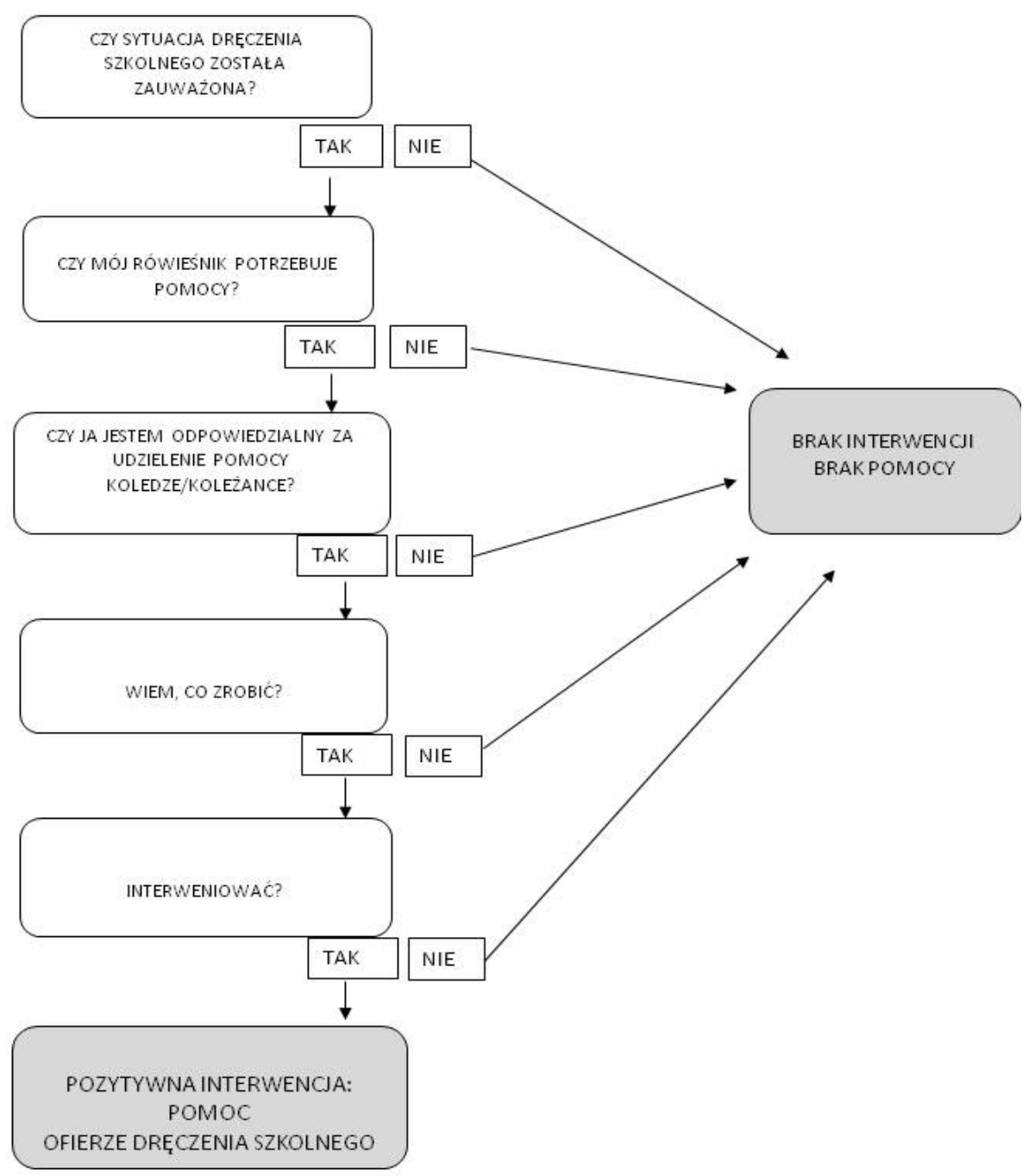

Ryc. 1. Decyzyjny model interwencji rówieśniczej w sytuacji dręczenia szkolnego (adaptacja własna wg modelu Latanego i Darleya)

W celu wyjaśnienia braku działania uczniów w sytuacji bycia świadkiem dręczenia szkolnego można odwołać się do decyzyjnego modelu interwencji kryzysowej ${ }^{15}$. Koncepcja ta zakłada, że udzielenie pomocy w sytuacji kryzysowej (a za taką można uznać przemoc rówieśniczą) wymaga spełnienia aż

15 B. Wojciszke, Relacje interpersonalne, [w:] Psychologia. Podręcznik akademicki. Jednostka w społeczeństwie i elementy psychologii stosowanej, red. J. Strelau, Gdańsk 2005, s. 164-166. 
pięciu warunków, podczas gdy do zaniechania pomocy wystarcza brak spełnienia zaledwie jednego warunku. Na każdym etapie mogą zadziałać pewne czynniki, które odwiodą obserwatora od udzielenia pomocy. Ten model decyzyjny możemy zaaplikować na grunt szkoły i zaadaptować do sytuacji dręczenia szkolnego (patrz ryc. 1). W efekcie umożliwi to nam zrozumienie, dlaczego tak niewielu uczniów decyduje się pomóc ofierze dręczenia szkolnego.

Pierwszy warunek polega na tym, by zdarzenie zauważyć. Z przytoczonych powyżej badań wiadomo, iż uczniowie raczej w większości zauważają przemoc wśród swoich rówieśników, więc warunek ten zostaje spełniony. Drugi warunek to zinterpretowanie sytuacji jako kryzysowej, czyli takiej, w której drugiej osobie potrzebna jest pomoc. Czynnikiem, który zmniejsza prawdopodobieństwo podjęcia działań prospołecznych przez uczniów w tej sytuacji może być po prostu brak jasnego zrozumienia procesu dręczenia szkolnego, brak wystarczającej wiedzy na ten temat. Dodatkowo, uczniowie obserwując brak reakcji u pozostałych uczniów przyglądających się całemu zdarzeniu, mogą dojść do wniosku, że nic "strasznego" się nie dzieje i pomoc nie jest nikomu potrzebna. Jest to proces tzw. niewiedzy wielu ${ }^{16}$. Okazuje się, że potrzebujemy dla swoich działań „,społecznego dowodu słuszności", który tym większe ma znaczenie, im bardziej sytuacja staje się niejasna, a także im bardziej nie jesteśmy pewni swoich działań. Ponadto, Olweus pisze, że $w$ efekcie powtarzanej przemocy szkolnej dochodzi do zmian poznawczych u uczniów ją obserwujących, ale też biorących w niej czynny udział17. Mianowicie, może ukształtować się przekonanie, że ofiara zasługuje na takie, a nie inne, traktowanie („sama jest sobie winna", „zasłużył sobie”). To z kolei może zmniejszyć odczuwanie poczucia winy przez uczniów, którzy biernie przyglądają się i nie pomagają w żaden sposób ofierze i wzmacnia przekonanie, że pomoc nie jest $w$ tej sytuacji potrzebna. U uczniów, którzy są świadkami/obserwatorami zdarzenia i wiedzą, że powinni pomóc, ale mimo wszystko nie robią tego, mogą zadziałać mechanizmy obronne, wyrażające się w próbie racjonalizacji swojego (braku) działania18. Najczęściej występującymi racjonalizacjami są: redefinicja zdarzenia polegająca na reinterpretowaniu

${ }^{16} \mathrm{R}$. Thornberg, A classmate in distress: schoolchildren as bystanders and their reason for how they act, Social Psychology of Education, 2007, 10(1), s. 5-28.

17 Cyt. za: A.L. Duffy, Bullying in Schools: A Social Identity Perspective, School of Applied Psychology, Griffith Business School, Griffith University 2004, s. 37-38.

18 Por. P. O'Connell, D. Pepler, W. Craig, Peer involvement in bullying: insights and challenges for intervention, Journal of Adolescence, 1999, 22, s. 437-452; T. Pozzoli, G. Gini, Active defending and passive bystanding behavior in bullying: the role of personal characteristics and perceived peer pressure, Journal of Abnormal Child Psychology, 2010, 38(6), s. 815-827; N. Willard, Positive Peer Intervention. Development of an Intervention Program that has a Likelihood of Success http:/ / www. embracecivility.org/wp-content/uploadsnew/2012/08/PositivePeerIntervention.pdf [dostęp: 07.10.2013]. 
doświadczenia w taki sposób, że staje się ono mniej obciążające (np. tłumaczenie "to tylko głupia zabawa"), czy pomniejszenie szkodliwych konsekwencji (np. "to nie jest nic strasznego", „nic mu nie będzie”).

Trzecim etapem jest przyjęcie odpowiedzialności osobistej za pomoc ofierze. Jednakże obecność innych uczniów-świadków dręczenia może spowodować rozproszenie odpowiedzialności. Po raz pierwszy mechanizm rozproszenia odpowiedzialności został zidentyfikowany $\mathrm{w}$ eksperymencie Darleya i Latane'a ${ }^{19}$. Rozproszenie odpowiedzialności u uczniów-świadków dręczenia szkolnego polega na obniżaniu się prawdopodobieństwa zareagowania wraz ze zwiększaniem się liczby świadków tego zdarzenia. A zatem, obecność przynajmniej jeszcze jednego świadka sprzyja uchylaniu się od odpowiedzialności za działanie interwencyjne.

Czwarta decyzja to rozstrzygnięcie świadka, czy ma on właściwe kompetencje do zainterweniowania (tj. czy wiem co zrobić? czy sobie poradzę?). Brak znajomości skutecznych strategii przeciwdziałania $\mathrm{w}$ takiej sytuacji może powodować bierność uczniów. Uczniowie mogą po prostu nie wiedzieć, co można zrobić $\mathrm{w}$ takiej sytuacji ${ }^{20}$, a nawet jeśli wiedzą - mogą nie wierzyć we własne siły, w skuteczność swojego działania.

I wreszcie ostatnia decyzja - podjęcie działania. Takie czyny mają niecodzienny charakter i poprzez tę nietypowość łatwo się przy nich ośmieszyć. Taki lęk przed ośmieszeniem się na oczach kolegów może skutecznie hamować podjęcie działania. Uczniom może się także wydawać, że swoimi działaniami tylko skomplikują sytuację, czy przyczynią się do jakichś dodatkowych problemów ${ }^{21}$. Ponadto, uczniowie są przekonani, że kiedy zareagują, sami narażą się na zostanie ofiarą w przyszłości²2. Dlatego, wolą godzić się na przemoc wobec swoich rówieśników z obawy (a może z troski?) o własne bezpieczeństwo, wybierając w ten sposób „mniejsze zło”.

Sygnalizowane powyżej mechanizmy są odpowiedzialne za brak reakcji rówieśników w sytuacji bycia świadkiem przemocy szkolnej. Jakkolwiek interwencja w sytuacji kryzysowej (lub jej brak) wygląda na prostą reakcję, w rzeczywistości poprzedzona jest co najmniej pięcioma decyzjami. Na każdy z tych mechanizmów i decyzji można wpływać za pomocą odpowiedniego kształtowania różnych elementów krytycznego zdarzenia. Znajomość tych mechanizmów umożliwia zaplanowanie działań, które pozwalają przełamać bierność uczniów-świadków i skłaniać ich do pomocy w sytuacji dręczenia szkolnego.

\footnotetext{
${ }^{19}$ Cyt. za: P. O'Connell, D. Pepler, W. Craig, Peer involvement in bullying, s. 439.

20 Por. K. Fenik, Psychologiczne aspekty bullyingu, s. 12.

${ }^{21}$ Cyt. za: G. Gini i in., Determinants of adolescents' active defending and passive bystanding behavior in bullying, Journal of Adolescence, 2008, 31, s. 101.

22 Por. P. O'Connell, D. Pepler, W. Craig, Peer involvement in bullying, s. 439.
} 


\section{Wyznaczniki pomagania}

Omówiony powyżej decyzyjny model interwencji kryzysowej pomaga zrozumieć, dlaczego uczniowie będący świadkami dręczenia szkolnego nie reagują i nie próbują pomóc ofierze. Koncepcja ta nie wyjaśnia jednak, co może skłaniać uczniów do udzielenia pomocy w takiej sytuacji. W psychologii społecznej znany jest model pobudzenia-bilansu (autorstwa Piliavin i współpracowników ${ }^{23}$ ), który naświetla z jednej strony, co może ludzi odwieść od udzielenia pomocy, z drugiej zaś - co skłania do jej wyświadczenia. Ów model zakłada, że do udzielania pomocy w sytuacji kryzysowej motywuje nas spostrzeganie jej jako skutecznego sposobu na usunięcie nieprzyjemnych emocji, które wywołane są cudzym nieszczęściem. Model ten zawiera trzy kluczowe twierdzenia: (1) zaobserwowanie cudzych kłopotów wywołuje $u$ obserwatora pobudzenie emocjonalne, które rośnie wraz z ich natężeniem, jednoznacznością i czasem trwania, a maleje wraz ze wzrostem dystansu oddzielającego świadka od osoby nękanej; (2) wywołane pobudzenie obserwatora jest dla niego nieprzyjemne i stara się on je zredukować tym bardziej, im jest ono silniejsze; (3) obserwator sytuacji kryzysowej wybiera taki sposób redukcji przeżywanego przez siebie pobudzenia, który działa najszybciej i wywołuje największy spadek przy stosunkowo najkorzystniejszym bilansie zysków i strat ${ }^{24}$. Warunkiem koniecznym do niesienia pomocy, według tego modelu, jest przekonanie obserwatora, że to opresja ofiary stanowi główny powód przeżywanego przezeń pobudzenia. Ponadto, model pobudzenia-bilansu uwzględnia dwa rodzaje kosztów, tj. koszty związane $\mathrm{z}$ udzieleniem pomocy $\mathrm{i}$ jej zaniechaniem. Zachowanie $\mathrm{w}$ sytuacji kryzysowej zależy zatem od wielkości kosztów zarówno udzielenia, jak i zaniechania pomocy. W przypadku dręczenia szkolnego kosztem udzielenia pomocy może być np. narażenie się na niebezpieczeństwo stania się ofiarą bullyingu $\mathrm{w}$ przyszłości, zaś zysk $\mathrm{z}$ pomocności to np. wzrost poczucia własnej skuteczności i samooceny lub podziw innych osób. Takie zyski mogą procentować w przyszłości, w podobnych sytuacjach. Badania Gini i współpracowników ${ }^{25}$ oraz Barchi i Bussey ${ }^{26}$ wykazały, że poczucie własnej skuteczności uczniów-świadków bullyingu jest pozytywnie związane z podejmowaniem zachowań mających na celu obronę ofiary przemocy rówieśniczej oraz koreluje ujemnie $\mathrm{z}$ byciem biernym $\mathrm{w}$ takiej sytuacji. Również

${ }^{23}$ Za: B. Wojciszke, Psychologia społeczna, Warszawa 2011, s. 353.

24 Tamże.

${ }^{25}$ G. Gini i in., Determinants of adolescents' active defending, s. 93-105.

${ }^{26} \mathrm{~K}$. Barchia, K. Bussey, Predictors of student defenders of peer aggression victims: empathy and social cognitive factors, International Journal of Behavioral Development, 2011, 35, s. 289-297. 
w badaniach Rigby'ego i Johnsona ${ }^{27}$ okazało się, że stosunkowo wysoki stopień poczucia własnej skuteczności jest charakterystyczny dla uczniów, którzy mają zamiar zainterweniować. Koszty zaniechania pomocy mogą mieć natomiast charakter osobisty i przybierać formę np. samoobwiniania się bądź empatyczny (np. własne cierpienie z powodu cierpienia ofiary, której się nie pomogło ${ }^{28}$. Przegląd kilkunastu badań nad pomocniczością i altruizmem dokonany przez Dovidio 29 doprowadził go do ogólnego wniosku, że postępowanie $\mathrm{w}$ sytuacji kryzysowej silniej zależy od wielkości kosztów udzielenia pomocy niż jej zaniechania. Ten rachunek zysków i strat także tłumaczyłby, dlaczego uczniowie raczej $w$ niewielkim stopniu angażują się w pomoc ofierze prześladowania szkolnego.

\section{Czynniki istotne dla pozytywnej interwencji rówieśników w sytuacji dręczenia szkolnego}

Jak wszystkie zachowania społeczne, pomaganie jest uwarunkowane zarówno czynnikami sytuacyjnymi, jak i indywidualnymi. Jednakże, czynniki sytuacyjne odgrywają tu znacznie większą rolę - pomaganie, czyli pozytywna interwencja, bardziej zależy od tego, w jakiej sytuacji ma dojść do pomocy, niż od tego, kto ma jej udzielić ${ }^{30}$.

Wiele wczesnych badań społecznych wykazało, że obecność innych, biernych obserwatorów hamuje pomaganie człowiekowi w potrzebie. Jest to nie tylko przejaw, wspomnianych wcześniej, procesów rozproszenia odpowiedzialności i niewiedzy wielu, ale także wyraz naśladowania innych w wyniku modelowania. W sytuacji dręczenia szkolnego możemy mieć do czynienia nie tylko z modelowaniem zachowań/braku działania świadków, ale także z modelowaniem zachowań agresywnych sprawców nękania. Olweus w 1978 roku opisał w kontekście dręczenia szkolnego mechanizmy, które prowadzą do tego, że uczniowie „z reguły” nieagresywni angażują się jednak $w$ przemoc rówieśniczą ${ }^{31}$ Pierwszy mechanizm to tzw. społeczne „zarażanie się", polegające na tym, że obserwowanie rówieśników dręczących kolegów zachęca obserwującego do podobnego działania, szczególnie

\footnotetext{
${ }^{27} \mathrm{~K}$. Rigby, B. Johnson, Expressed readiness of Australian schoolchildren to act as bystanders in support of children who are being bullied, Educational Psychology, 2006, 26(3), s. 425-440.

28 B. Wojciszke, Psychologia społeczna, s. 353.

${ }^{29}$ J.F. Dovidio, Helping behavior and altruism: An empirical and conceptual review, Advances in Experimental Social Psychology, 1984, 84, s. 682-696.

30 Por. B. Wojciszke, Psychologia społeczna, s. 362.

${ }^{31}$ Cyt. za: A.L. Duffy, Bullying in Schools: A Social Identity Perspective, Griffith University, 2004, s. 37.
} 
kiedy obserwowany sprawca jest skuteczny w swych działaniach. Drugi mechanizm związany jest $\mathrm{z}$ osłabieniem zahamowania przeciwko agresywnym zachowaniom. Następuje ono wówczas, kiedy dziecko widzi, że sprawca dręczenia szkolnego jest nagradzany za swoje agresywne zachowanie. Taką sytuacją jest np. zwycięstwo w bójce $\mathrm{z}$ ofiarą lub brak jakiejkolwiek interwencji ze strony nauczyciela, który wie o całym zajściu. Branie udziału $\mathrm{w}$ takiej sytuacji lub obserwowanie jej z boku obniża własne zahamowanie przed angażowaniem się w działania agresywne. Bandura w roku 197732, w swojej teorii społecznego uczenia się, wskazał warunki zwiększające prawdopodobieństwo uczenia się przez modelowanie, do których należą: (1) działający model postrzegany jest jako silna, wyrazista osoba; (2) model jest $\mathrm{w}$ jakimś stopniu podobny (ma wspólne cechy) do osoby go obserwującej oraz (3) model zostaje nagrodzony za swoje działanie. W przypadku bullyingu czynniki te zostają często spełnione. Jednakże, tym wyróżniającym się i silnym modelem jest raczej sprawca dręczenia szkolnego.

Z drugiej zaś strony, skoro zachowanie modeli może wzmagać agresywność i hamować prospołeczność, to powinno być także w stanie ją nasilić. Istotnie, liczne badania wykazały, że zaobserwowanie innej, prospołecznie postępującej osoby wzmaga skłonność do pomagania ${ }^{33}$. Ponadto, naśladowanie pomagania występuje $\mathrm{w}$ następstwie modeli obserwowanych zarówno na żywo, jak i w telewizji. Ustalono także, że treść bieżących myśli, czy samo zaktywizowanie kategorii prospołecznych w umyśle przez obserwację zachowania innych, nasila skłonność do pomocy i współpracy ${ }^{34}$. Pomagania zatem można nauczyć się na zasadzie modelowania. Nie prowadzono jednak badań dotyczących modelowania zachowań pomocnych i wspierających ofiarę w kontekście bullyingu.

$\mathrm{Na}$ podstawie przeprowadzonych dotychczas studiów empirycznych (głównie zagranicznych) na temat interwencji rówieśników w sytuacji dręczenia szkolnego, udało się udokumentować rolę pewnych czynników zwiększających prawdopodobieństwo interwencyjnego działania uczniów (patrz ryc. 2). Czynniki te nabierają szczególnego znaczenia przy podejmowaniu decyzji o pomocy ofierze dręczenia szkolnego.

Wśród czynników kontekstowych istotnego znaczenia nabierają normy rówieśnicze oraz percepcja tych norm i oczekiwań ze strony rówieśników. Dziesiątki lat badań w psychologii społecznej wiodą nas do eksperymentów Solomona Ascha i Musafera Sherifa, demonstrujących silną tendencję ludzi do konformizmu wobec norm grupowych. Oczywiście, wielu ludzi (szczegól-

\footnotetext{
32 A. Bandura, Teoria społecznego uczenia się, Warszawa 2007.

33 B. Wojciszke, Psychologia społeczna, s. 362.

34 Tamże, s. 363.
} 


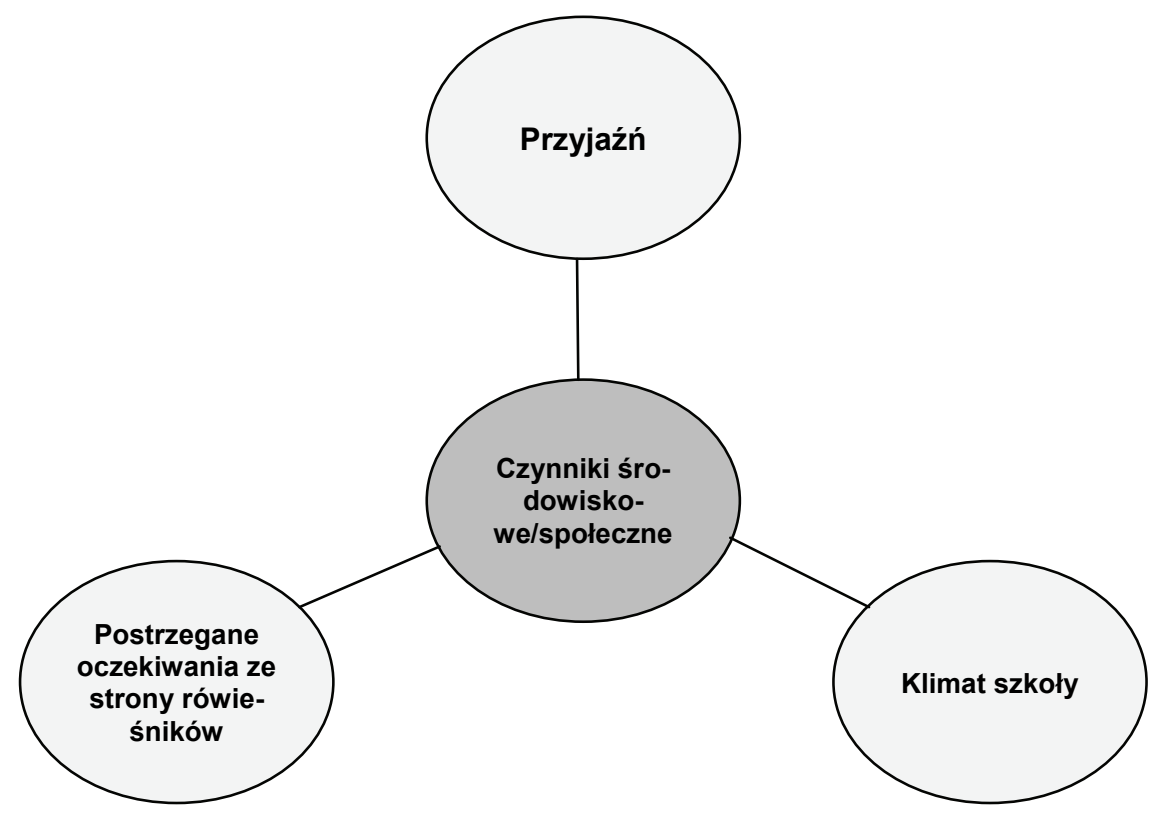

Ryc. 2. Czynniki kontekstowe zwiększające prawdopodobieństwo pozytywnej interwencji rówieśników w sytuacji dręczenia szkolnego (opracowanie własne na podstawie cytowanej literatury)

nie zaś nastolatkowie) postrzega siebie jako indywidualistów, ale mimo to znaczny stopień wpływu rówieśników jest konsekwentnie dokumentowany $\mathrm{w}$ badaniach eksperymentalnych, sondażowych, czy opartych na codziennych obserwacjach zachowań $\mathrm{w}$ tłumie ${ }^{35}$. Dręczenie szkolne jest $\mathrm{z}$ natury procesem relacyjnym, opierającym się na dominacji, opanowywaniu i apatii świadków tych zachowań, kształtowanym głównie przez normy grupowe ${ }^{36}$. Teoria norm społecznych sugeruje, że niewłaściwe postrzeganie postaw i zachowań innych zmniejsza chęć interwencji zapobiegającej przemocy37. Jak się jednak okazuje, uczniowie angażujący się w bullying jako sprawcy

${ }^{35}$ H.W. Perkins, D.W. Craig, J.M. Perkins, Using social norms to reduce bullying: A research intervention among adolescents in five middle schools, Group Process \& Intergroup Relations, 2011, 14(5), s. 704.

36 Tamże, s. 705.

37 Por. A.D. Berkowitz, Fostering Healthy Norms to Prevent Violence and Abuse: The Social Norms Approach, [w:] The Prevention on Sexual Violence: A Practitioner's Sourcebook, red. K. Kaufman, Morgan-Washington 2010.

http://www.alanberkowitz.com/articles/Preventing\%20Sexual\%20Violence\%20Chapter \%20-\%20Revision.pdf [dostęp 14.10.2013]. 
postrzegani są przez rówieśników jako uczniowie popularni i „fajni”, co z kolei przyczynia się do tego, że uczniowie nie opowiadają się po stronie ofiary, bo jest ona w opozycji do cieszącego się popularnością rówieśnika. Postrzegane oczekiwania ze strony rówieśników zostały zidentyfikowane jako istotny czynnik moderujący zaangażowanie się uczniów-świadków dręczenia szkolnego ${ }^{38}$. To co uczeń myśli, że pozostali jego rówieśnicy uważają za słuszne, czy za niewłaściwe, co myślą o tych osobach, które pomagają, zdaje się mieć znaczenie w tej sytuacji. Uczniowie często zachowują się w zgodzie z postrzeganymi przez nich normami grupowymi. Jeśli normy te zniechęcają do agresji rówieśniczej i wspierają pozytywne interwencje, liczba uczniów, którzy są skłonni nieść pomoc, wzrasta. Z tego punktu widzenia ważne jest wdrażanie w programach profilaktycznych działań mających na celu wzmacnianie pozytywnych norm rówieśniczych, czyli takich, które wspierają osoby krzywdzone, podziwiają osoby pomocne oraz dezaprobują zachowujących się agresywnie. Juvonen i Galvan sugerują39, że normy rówieśnicze są kreowane przez uczniów popularnych, zajmujących wysoką pozycję socjometryczną. Dlatego, należałoby mobilizować właśnie tych uczniów do wspierania ofiar przemocy szkolnej. Mogliby oni wówczas stanowić także dobre wzorce do naśladowania.

Nie bez znaczenia są także bliskie relacje z rówieśnikami, szczególnie relacje przyjacielskie. Brak bliskiego przyjaciela może być, po pierwsze, czynnikiem ryzyka doświadczenia agresji rówieśniczej, bowiem osoba bez wsparcia społecznego może stanowić „łatwiejszy” dla sprawcy cel, którego nikt nie będzie bronił, a także po drugie - wskaźnik, że dany uczeń jest ofiarą, z którą nikt z grupy „nie chce się zadawać" 40 . Z badań Oh i Hazlera41 wynika, że uczniowie-świadkowie przemocy rówieśniczej byli mniej skłonni do podejmowania interwencji wówczas, gdy byli w bliskiej relacji ze sprawcą. Wówczas wzrastało prawdopodobieństwo, że świadek raczej będzie wspierał swojego agresywnego kolegę. Sytuacja wyglądała odwrotnie, kiedy

${ }^{38}$ T. Pozzoli, G. Gini, Active defending and passive bystanding behavior in bullying: the role of personal characteristics and perceived peer pressure, Journal of Abnormal Child Psychology, 2010, 38(6), s. 815-827; K. Rigby, B. Johnson, Expressed readiness of Australian schoolchildren to act as bystanders in support of children who are being bullied, Educational Psychology, 2006, 26(3), s. 425440; C. Salmivalli, Bullying and the Peer Group, s. 112-120.

${ }^{39}$ Cyt. za: V. Pöyhönen, J. Juvonen, C. Salmivalli, What does it take to stand up for the victim of bullying? The interplay between personal and social factors, Merrill-Palmer Quarterly, 2010, 56(2), s. 160 .

40 Por. A. Tłuściak-Deliowska, Zaangażowanie gimnazjalistów w przemoc rówieśniczą. Rola bliskich przyjaźni. Komunikat z badań, Wychowanie na co Dzień (w druku).

${ }^{41} \mathrm{I}$. Oh, R.J. Hazler, Contributions of personal and situational factors to bystanders' reactions to school bullying, School Psychology International, 2009, 30, s. 291-310. 
to ofiara była bliskim przyjacielem obserwatora. Natomiast, jeśli uczeńświadek nie jest przyjacielem ani sprawcy, ani ofiary, najczęściej pozostaje biernym obserwatorem lub może pośredniczyć w konflikcie jako mediator ${ }^{42}$. I na tym ostatnim, z pedagogicznego punktu widzenia, zależałoby by nam najbardziej. Istotne jest zatem rozwijanie kompetencji mediacji w przypadku konfliktów rówieśniczych przez uczniów „neutralnych”.

Jeszcze jednym czynnikiem kontekstowym, na który chciałabym zwrócić uwagę, jest klimat szkoły. Stanowi bowiem tło dla analizowanych zachowań szkolnych. Społeczny klimat szkoły może wpływać na zaangażowanie uczniów w zachowania agresywne. Z badań Ma ${ }^{43}$ wynika, że szkoły, w których bullying występuje tylko $\mathrm{w}$ niewielkim nasileniu, charakteryzują się podejmowaniem pozytywnych działań dyscyplinujących, silnym zaangażowaniem rodziców w życie szkoły i wysokimi standardami kształcenia. Wyniki badań przeprowadzonych przez Lindstroom Johnson i jej współpracowników ${ }^{44}$ dowodzą, że klimat szkoły istotnie wpływa na reakcje uczniów będących świadkami bullyingu i nie tylko. Uczniowie będący ofiarami dręczenia szkolnego, którzy nie czuli się w swojej szkole bezpiecznie, sami częściej odpowiadali zachowaniami agresywnymi. Programy profilaktyczne i interwencyjne powinny uwzględniać zatem klimat szkoły jako potencjalny czynnik przyczyniający się do wzmacniania lub hamowania dręczenia szkolnego ${ }^{45}$. Uczniowie powinni mieć możliwość wypowiedzenia się, jak czują się w swojej szkole, czy czują się z nią związani i w niej szanowani, jak nauczyciele i administracja szkoły postrzegają bullying, w jaki sposób obchodzi się z sygnałami o incydentach przemocowych w szkole, czy w szkole akceptuje się różnorodność itp. Te aspekty odgrywają istotną rolę w sposobie, $\mathrm{w}$ jaki traktują się uczniowie ${ }^{46}$, co z kolei ma swoje odzwierciedlenie $\mathrm{w}$ klimacie szkoły.

42 N. Willard, Positive Peer Intervention. Development of an Intervention Program that has a Likelihood of Success, 2013 http://www.embracecivility.org/wp-content/uploadsnew/2012/ 08/PositivePeerIntervention.pdf [dostęp: 07.10.2013].

${ }^{43} \mathrm{X} . \mathrm{Ma}$, Bullying in middle school: Individual and school characteristics of victims and offenders, School Effectiveness and School Improvement, 2002, 13, s. 63-89.

${ }^{44}$ S. Lindstrom Johnson i in., The Role of Bystander Perceptions and School Climate in Influencing Victims' Responses to Bullying: To Retaliate or Seek Support? Journal of Criminology, 2013 http://dx.doi.org/10.1155/2013/780460

${ }_{45}$ Zob. S.S. Leff $\mathrm{i}$ in., Assesing the climate of the playground and lunchroom: Implication for bullying prevention programming, School Psychology Review, 2003, 32, s. 418-430; A. Guarini i in., Risk and protective factors on perpetration of bullying and cyberbullying, Studia Edukacyjne, 2012, 23, s. 33-55.

${ }^{46}$ D.L. Espelage, S.M. Swearer, Research on School Bullying and Victimization: What Have We Learned and Where Do We Go From Here? School Psychology Review, 2003, 32(3), s. 378. 


\section{Programy profilaktyczne i interwencyjne}

O skutecznej doraźnej interwencji mówimy wówczas, kiedy dręczenie szkolne zostaje przerwane $\mathrm{w}$ ciągu 10 sekund po zaistnieniu próby pomo$\mathrm{cy}^{47}$. Interwencja może być ukierunkowana na osobę sprawcy przemocy szkolnej, na ofiarę lub zarówno na sprawcę, jak i ofiarę. Interwencja skierowana na sprawcę uwzględnia np. żądanie od sprawcy by przestał dręczyć drugą osobę lub fizyczną próbę powstrzymania agresora. Interwencja skierowana na ofiarę uwzględnia pomoc ofierze, osłonięcie jej, wsparcie. Interwencja skierowana i na sprawcę, i na ofiarę uwzględnia np. wejście pomiędzy nich. Howkins, Pepler i Craig48 przyjrzały się, jak wyglądają interwencje uczniów w wieku 6-12 lat w takich sytuacjach. Okazało się, że interwencje skierowane na sprawcę dręczenia miały zazwyczaj charakter agresywny (np. powstrzymanie go siłą, wyzywanie), natomiast interwencje skierowane na ofiarę były nie-agresywne. Większość dzieci interweniowała w sposób społecznie akceptowalny i nieagresywny. Trzy czwarte interwencji rówieśników przyniosły efekt $\mathrm{w}$ postaci zatrzymania przemocy rówieśniczej. Badania te potwierdzają zatem, że rówieśnicy mogą skutecznie interweniować, jednocześnie zaś sygnalizują pewne obawy w stosunku do niektórych stosowanych przez nie strategii. Chodzi tutaj o interwencje agresywne ukierunkowane na sprawcę przemocy rówieśniczej. Być może uczniowie wybierali takie właśnie działania, ponieważ wcześniejsze doświadczenia pokazały im, że tylko taki sposób jest skuteczny w takiej sytuacji. W konsekwencji, należałoby $\mathrm{w}$ większym stopniu uczyć dzieci i młodzież prospołecznych strategii interwencji.

O'Connell, Pepler i Craig zwracają uwagę ${ }^{49}$, że efektywne interwencje angażujące grupę rówieśniczą $\mathrm{w}$ zapobieganie i ograniczanie dręczenia szkolnego powinny skupiać się na dwóch elementach. Po pierwsze, istotne jest podnoszenie świadomości uczniów o ich osobistej odpowiedzialności w sytuacji dręczenia szkolnego i roli empatii dla ofiary przemocy szkolnej. Po drugie, niezbędne jest wprowadzenie efektywnych strategii zapobiegawczych dla dzieci i młodzieży oraz zachęcanie ich do przeciwstawiania się negatywnemu wpływowi grupy rówieśniczej. W rezultacie, efektywne strategie mogą zmobilizować "cichą większość” do aktywnego działania przeciwko bullyingowi.

47 D.L. Hawkins, D.J. Pepler, W.M. Craig, Naturalistic observations of peer interventions in bullying, Social Development, 2001, 10, s. 525.

48 Tamże, s. 512-527.

${ }^{49}$ P. O'Connell, D. Pepler, W. Craig, Peer involvement in bullying, s. 450. 
Próba zmiany postaw dzieci i młodzieży może być dobrym punktem wyjścia, aczkolwiek znacznie istotniejszym problemem zdaje się tutaj być kwestia: w jaki sposób przyczynić się do tego, by przekształcić postawy uczniów dezaprobujące przemoc $\mathrm{w}$ rzeczywiste zachowanie $\mathrm{w}$ sytuacji dręczenia szkolnego. Podnoszenie świadomości dzieci i młodzieży na temat zjawiska bullyingu może być pierwszym krokiem ku zmianie ${ }^{50}$. Może on być realizowany poprzez np. rozmowy i dyskusje w całej klasie, począwszy od tego, czym jest dręczenie szkolne, jak czuje się w takiej sytuacji ofiara, sprawca, świadek, skończywszy na analizie mechanizmów grupowych wyjaśniających zachowanie poszczególnych osób. Ważne staje się zwrócenie uwagi na to, że w grupie często zachowujemy się inaczej, niż kiedy jesteśmy sami oraz pomimo tego, że wiemy, jak należałoby zachować się $w$ danej sytuacji, nie zawsze tak postępujemy. Uświadomienie uczniom rozbieżności pomiędzy tym, co uważamy za słuszne, a tym, jak postępujemy, może stanowić dobry grunt do dalszej zmiany postaw i zachowań. Kolejnym krokiem, zdaniem Salmivalli i współpracowników ${ }^{51}$, powinno być zachęcanie do autorefleksji, a dokładniej - zastanowienie się nad tym, jaka jest moja rola w przemocy szkolnej? Co oznacza moje zachowanie dla sprawcy, ofiary i pozostałych uczniów? Ważne jest, by uczniowie uświadomili sobie, że ten, kto nic nie robi, ale biernie uczestniczy w szykanowaniu kolegów, jest niejako współsprawcą bullyingu i ponosi indywidualną odpowiedzialność 52 . Uczniowie nie zawsze zdają sobie sprawę z tego, jak szkodliwe jest ich postępowanie. Trzecim etapem może być przyjęcie zobowiązania do podejmowania zachowań antyprzemocowych, wspierane poprzez wskazywanie różnych właściwych sposobów zachowania się w sytuacji dręczenia szkolnego. W tej sytuacji odgrywanie scenek i ich analiza może być właściwą metodą realizacji tych zamierzeń. Dodatkowo, właściwe zachowania mogą być wspierane poprzez normy klasowe, ustalone przez całą grupę, przez nią przyjęte i przestrzegane (np. zasada ,jeśli widzisz przemoc rówieśniczą, pokaż, że nie akceptujesz tego"). Z moich badań nad związkiem między percepcją klimatu szkoły a aprobatą przemocy, przeprowadzonych wśród 690 uczniów w wieku od 13 do 19 lat, wynika, że poczucie klarowności sytuacji, obowiązywania pewnych reguł w szkole i ich konsekwentnego przestrzegania zmniejsza poziom aprobaty uczniów dla przemocy w życiu społecznym oraz zapewnia poczucie bezpieczeństwa ${ }^{53}$.

50 C. Salmivalli, A. Kaukiainen, M. Voeten, Anti-bullying intervention: Implementation and outcome, British Journal of Educational Psychology, 2005, 75, s. 467.

51 Tamże, s. 468.

52 D. Olweus, Mobbing. Fala przemocy w szkole, s. 94.

53 A. Tłuściak-Deliowska, Percepcja klimatu szkoty a aprobata przemocy $i$ uprzedzenia etniczne wśród nastolatków, niepublikowana rozprawa doktorska, Warszawa 2012; tejże, Wybrane aspekty 
Program interwencyjny ukierunkowany na grupę jako całość, podkreślający zaangażowanie $\mathrm{w}$ bullying wszystkich uczniów i uwzględniający omówione powyżej elementy został wprowadzony przez Salmivalli i współpracowników ${ }^{54}$. Jego rezultaty były pozytywne $w$ wielu obszarach, m.in. zaobserwowano mniejszą częstotliwość bullyingu. Jednakże, obserwowane efekty były większe wśród uczniów młodszych niż starszych. Również badania Trach i współpracowników potwierdzają ${ }^{55}$, że podejmowanie strategii na rzecz promowania pozytywnych zachowań $\mathrm{w}$ sytuacji dręczenia szkolnego jest bardziej efektywne wśród uczniów młodszych, ze szkół podstawowych. Uczniowie ci są bardziej skłonni do podejmowania wyraźnych, bezpośrednich działań, niż do pasywnego przyglądania się sytuacji. Oznacza to, że programy profilaktyczne zapobiegające bullyingowi należy wprowadzać odpowiednio wcześnie, tj. w szkołach podstawowych i opracować takie, będące ich kontynuacją podczas dalszej edukacji. Należy także programy profilaktyczne i interwencyjne dostosowywać do zmian rozwojowych oraz społecznych dzieci i młodzieży.

Polanin, Espelage i Pigott dokonali metaanalizy 12 programów zapobiegających bullyingowi w szkole, ukierunkowanych na pozytywne zaangażowanie uczniów-świadków przemocy rówieśniczej ${ }^{56}$. Wyniki analiz potwierdzają skuteczność tych programów, które podnoszą świadomość uczniów na temat ich roli $\mathrm{w}$ dręczeniu szkolnym, zachęcają do aktywnych i prospołecznych działań oraz stanowią okazję do odgrywania ról i doświadczania różnych scenariuszy. Wyniki metaanaliz ujawniły także, że programy profilaktyczne mogą być efektywne we wspieraniu prospołecznych interwencji uczniówświadków dręczenia szkolnego, jeśli programy te są bezpośrednio ukierunkowane jednocześnie na kształtowanie postaw uczniów i ich zachowań. Nie jest zatem wystarczające jedynie zdefiniowanie i określenie, jakie role i zachowania są potrzebne i oczekiwane $\mathrm{w}$ sytuacji bycia świadkiem/obserwatorem przemocy rówieśniczej. Należy opracowywać i adaptować programy kształtujące postawy aprobujące pozytywną interwencję i jednocześnie kształtujące takie zachowania pomocne. Wszystkie działania powinny wynikać ze spójnej wizji zabiegów rekomendowanych przez dorosłych ${ }^{57}$.

klimatu szkoły a postawy uczniów wobec przemocy w życiu społecznym, Ruch Pedagogiczny, 2013, 4, s. 77-88.

${ }^{54}$ C. Salmivalli, A. Kaukiainen, M. Voeten, Anti-bullying intervention, s. 465-487.

$55 \mathrm{~J}$. Trachet $\mathrm{i}$ in., Bystander responses to school bullying: A cross-sectional investigation of grade and sex differences, Canadian Journal of Psychology, 2010, 25(1), s. 114-130.

56 J.R. Polanin, D.L. Espelage, T.D. Pigott, A Meta-Analysis of School-Based Bullying Prevention Programs' Effect on Bystander Intervention Behavior, School Psychology Review, 2012, 41(1), s. $47-65$.

57 Tamże, s. 61-62. 


\section{Wnioski końcowe}

Podsumowując przedstawione informacje, należy podkreślić, że skoro rówieśnicy są obecni w ogromnej większości sytuacji dręczenia szkolnego, stanowią oni potencjał do przeciwdziałania zjawisku bullyingu. Dlatego, programy profilaktyczne i interwencyjne powinny uwzględniać problematykę roli uczniów-świadków. Celem zwiększenia liczby pozytywnych interwencji wśród rówieśników należy $\mathrm{w}$ programach profilaktycznych uwzględniać zarówno czynniki osobowe, jak i zasygnalizowane wcześniej uwarunkowania kontekstowe.

Programy profilaktyczne ukierunkowane na grupę rówieśniczą muszą być jednocześnie wzmacniane przez szersze rozwiązania systemowe. Podejście obejmujące całą szkołę, łącznie z uczniami, nauczycielami, administracją szkoły i rodzicami może z powodzeniem obalić istniejące społeczne warunki (związane także z funkcjonowaniem grupy rówieśniczej), które, jak się okazuje, sprzyjają i czasami "przez przypadek” wzmacniają bullying, jak też wiktymizację uczniów.

\section{BIBLIOGRAFIA}

Bandura A., Teoria społecznego uczenia się, Wydawnictwo Naukowe PWN, Warszawa 2007.

Barchia K., Bussey K., Predictors of student defenders of peer aggression victims: empathy and social cognitive factors, International Journal of Behavioral Development, 2011, 35, s. 289-297.

Berkowitz A.D., Fostering Healthy Norms to Prevent Violence and Abuse: The Social Norms Approach, [w:] The Prevention on Sexual Violence: A Practitioner's Sourcebook, red. K. Kaufman, NEARI Press, Morgan-Washington 2010.

Dovidio J.F., Helping behavior and altruism: An empirical and conceptual review, Advances in Experimental Social Psychology, 1984, 84.

Duffy A.L., Bullying in Schools: A Social Identity Perspective, School of Applied Psychology, Griffith Business School, Griffith University 2004.

Espelage D.L., Swearer S.M., Research on School Bullying and Victimization: What Have We Learned and Where Do We Go From Here? School Psychology Review, 2003, 32(3).

Fenik K., Psychologiczne aspekty bullyingu: perspektywa sprawcy, ofiary i świadka. Materiał z konferencji „Szkoła wolna od przemocy. Jak sobie radzić z bullyingiem?” 11.04.2013, Warszawa 2013.

Gini G., Albiero P., Benelli B., Altoe G., Determinants of adolescents' active defending and passive bystanding behavior in bullying, Journal of Adolescence, 2008, 31.

Giza-Poleszczuk A., Komendant-Brodowska A., Baczko-Dombi A., Przemoc w szkole, Raport z badań. Maj 2011.

Guarini A., Passini S., Melotti G., Brighi A., Risk and protective factors on perpetration of bullying and cyberbullying, Studia Edukacyjne, 2012, 23. 
Hawkins D.L., Pepler D.J., Craig W.M., Naturalistic observations of peer interventions in bullying, Social Development, 2001, 10.

Kärnä A., Voeten M., Poskiparta E., Salmivalli C., Vulnerable children in varying classroom contexts: bystanders' behaviors moderate the effects of risk factors on victimization, MerrillPalmer Quarterly, 2010, 56(3).

Leff S.S., Power T.J., Costigan T.E., Manz P.H., Assesing the climate of the playground and lunchroom: Implication for bullying prevention programming, School Psychology Review, $2003,32$.

Lindstrom Johnson S., Waasdorp T.E., Dednam K., Bradshaw C.P., The Role of Bystander Perceptions and School Climate in Influencing Victims' Responses to Bullying: To Retaliate or Seek Support? Journal of Criminology, 2013 http://dx.doi.org/10.1155/2013/ 780460

Ma X., Bullying in middle school: Individual and school characteristics of victims and offenders, School Effectiveness and School Improvement, 2002, 13.

O'Connell P., Pepler D., Craig W., Peer involvement in bullying: insights and challenges for intervention, Journal of Adolescence, 1999, 22.

Oh I., Hazler R.J., Contributions of personal and situational factors to bystanders' reactions to school bullying, School Psychology International, 2009, 30.

Olweus D., Mobbing. Fala przemocy w szkole. Jak ja powstrzymać? Przekł. D. Jastrun, Jacek Santorski \& Co Agencja Wydawnicza, Warszawa 2007.

Olweus D., Przemoc w szkołach. Prezentacja na Europejskim Kongresie Przeciwdziałania Przemocy Szkolnej, Warszawa 15.09.2010.

Pepler D.J., Craig W.M., A peek behind the fence: naturalistic observations of aggressive children with remote audiovisual recording, Developmental Psychology, 1995, 31.

Perkins H.W., Craig D.W., Perkins J.M., Using social norms to reduce bullying: A research intervention among adolescents in five middle schools, Group Process \& Intergroup Relations, 2011, 14(5).

Polanin J.R., Espelage D.L., Pigott T.D., A Meta-Analysis of School-Based Bullying Prevention Programs' Effect on Bystander Intervention Behavior, School Psychology Review, 2012, 41(1).

Pöyhönen V., Juvonen J., Salmivalli C., What does it take to stand up for the victim of bullying? The interplay between personal and social factors, Merrill-Palmer Quarterly, 2010, $56(2)$.

Pozzoli T., Gini G., Active defending and passive bystanding behavior in bullying: the role of personal characteristics and perceived peer pressure, Journal of Abnormal Child Psychology, 2010, 38(6).

Rigby K., Przemoc w szkole. Jak ją ograniczać. Poradnik dla rodziców i pedagogów, przekł. R. Mitoraj, Wydawnictwo UJ, Kraków 2010.

Rigby K., Johnson B., Expressed readiness of Australian schoolchildren to act as bystanders in support of children who are being bullied, Educational Psychology, 2006, 26(3).

Salmivalli C., Participant role approach to school bullying: implications for intervention, Journal of Adolescence, 1999, 22.

Salmivalli C., Bullying and the Peer Group: A Review, Aggression and Violent Behavior, 2010, 15.

Salmivalli C., Kaukiainen A., Voeten M., Anti-bullying intervention: Implementation and outcome, British Journal of Educational Psychology, 2005, 75. 
Salmivalli C., Lagerspetz K., Bjorkvist K., Osterman K., Kaukiainen A., Bullying as a Group Process: Participants Roles and Their Relation to Social Status within the Group, Aggressive Behavior, 1996, 22.

Salmivalli C., Voeten M., Connections between attitudes, group norms, and behavior in bullying situations, International Journal of Behavior Development, 2004, 28(3).

Salmivalli C., Voeten M., Poskiparta E., Bystanders Matter: Association Beetween Reinforcing, Defending and the Frequency of Bullying Behavior in Classrooms, Journal of Clinical Child \& Adolescence Psychology, 2011, 40(5).

Swearer S.M., Espelage D.L., Vaillancourt T., Hymel Sh., What Can Be Done About School Bullying? Linking Research to Educational Practice, Educational Researcher, 2010, 39(1).

Thornberg R., A classmate in distress: schoolchildren as bystanders and their reason for how they act, Social Psychology of Education, 2007, 10(1).

Thornberg R., Tenenbaum L., Varjas K., Meyers J., Jungert T., Vanegas G., Bystander Motivation in Bullying Incidents: To Intervene or Not to Intervene? Western Journal of Emergency Medicine, 2012, 13(3).

Tłuściak-Deliowska A., Percepcja klimatu szkoty a aprobata przemocy $i$ uprzedzenia etniczne wśród nastolatków, niepublikowana rozprawa doktorska, Wydział Nauk Pedagogicznych, Akademia Pedagogiki Specjalnej im. M. Grzegorzewskiej w Warszawie, 2012.

Tłuściak-Deliowska A., Deklaracje postaw wobec przemocy rówieśniczej wśród gimnazjalistów, Psychologia Rozwojowa, 2013, 3.

Tłuściak-Deliowska A. (w druku), Zaangażowanie gimnazjalistów w przemoc rówieśnicza. Rola bliskich przyjaźni. Komunikat z badań, Wychowanie na co Dzień.

Trach J., Hymel S., Waterhouse T., Neale K., Bystander responses to school bullying: A crosssectional investigation of grade and sex differences, Canadian Journal of Psychology, 2010, 25(1).

Whitney I., Smith P.K., A survey of the nature and extent of bullying in junior/Middle and secondary schools, Educational Research, 1993, 35.

Willard N., Positive Peer Intervention. Development of an Intervention Program that has a Likelihood of Success, 2013.

Wojciszke B., Relacje interpersonalne, [w:] Psychologia. Podręcznik akademicki. Jednostka w społeczeństwie i elementy psychologii stosowanej, red. J. Strelau, Gdańskie Wydawnictwo Psychologiczne, Gdańsk 2005.

Wojciszke B., Psychologia społeczna, Wydawnictwo Naukowe Scholar, Warszawa 2011.

http:/ / www.alanberkowitz.com/articles/Preventing\%20Sexual\%20Violence\%20Chapter $\% 20-\% 20$ Revision.pdf [dostęp 14.10.2013].

http://www.embracecivility.org/wpcontent/uploadsnew/2012/08/PositivePeerIntervention.pdf [dostęp 07.10.2013].

http:/ / www.ore.edu.pl/strona-ore/index.php?option=com_phocadownload\&view=cate gory\&id=55:profilaktyka-agresji-i-przemocy\&Itemid=1148 [dostęp 07.10.2013]. 